\title{
The first report on the phenomenon of Capoeta aydinensis (Cyprinidae), occurring in Gökova Bay, Aegean Sea
}

\section{Gökova Körfezi'nde (Ege Denizi) Capoeta aydinensis (Cyprinidae) olgusu hakkında illk rapor}

\author{
Okan Akyol1* ${ }^{1 *}$ Vahdet Ünal ${ }^{2}$ • Hasan M. Sarl ${ }^{3}$
}

\footnotetext{
${ }^{1}$ Ege University Faculty of Fisheries, 35440 Urla, Izmir, Turkey

${ }^{2}$ Ege University Faculty of Fisheries, 35440 Urla, Izmir, Turkey

${ }^{3}$ Ege University Faculty of Fisheries, 35440 Urla, Izmir, Turkey
}

Abstract: A big specimen of Capoeta aydinensis ( $435 \mathrm{~mm}$ TL, $1040 \mathrm{~g}$ ) was caught on 22 March 2020 by an angler from the Gökova Bay, Muğla as an unusual habitat. This case report presents occurring of an endemic freshwater fish in the marine waters and this specimen has the maximum size throughout the Anatolia.

Keywords: Size, freshwater fish, measurement, Akçapınar stream delta, Muğla

Öz: 22 Mart 2020'de büyük bir Capoeta aydinensis örneği (435mm TL, 1040 g) olağandıșı bir yaşam alanı olarak Muğla Gökova Körfezi'nden bir oltacı tarafından yakalanmışıı. Bu olgu sunumu, deniz sularında endemik bir tatı su balığının bulunuşunu göstermektedir ve bu örnek Anadolu genelinde maksimum büyüklüğe sahiptir.

Anahtar kelimeler: Boyut, tatı su balığı, ölçüm, Akçapınar ırmak deltası, Muğla

\section{INTRODUCTION}

As a new endemic freshwater species, Capoeta aydinensis Turan, Küçük, Kaya, Güçlü \& Bektaş, 2017 was described from the Büyük Menderes River and Tersakan, Dalaman, and Namnam streams in southwestern Turkey (Turan et al., 2017). C. aydinensis can be diagnosed from its congeners in the Mediterranean and in Anatolia by a combination of characters (Froese and Pauly, 2019). It is distinguished from the other Capoeta species by the following characters: one pair of barbel; a plain brownish body coloration; a well-developed keel in front of the dorsal-fin origin; a slightly arched mouth; a slightly convex lower jaw with a well-developed keratinized edge; a weakly ossified last simple dorsal-fin ray, serrated along about $60 \%-70 \%$ of its length, with $14-20$ serrae along its posterior edge; $58-71$ total lateral line scales; 11-12 scale rows between lateral line and dorsal-fin origin; 7-9 scale rows between lateral line and analfin origin (Turan et al., 2017).

The recent study reported that maximum age of $C$. aydinensis was 8 years; and its habitat preference is shady areas in spring, generally blurry waters in summer, high vegetation cover and blurry waters in autumn and high vegetation cover in winter (Akbaş et al., 2019). As an unusual habitat, this case report presents occurrence of an endemic fresh water fish, Capoeta aydinensis in marine waters of Gökova Bay, Aegean Sea.

\section{MATERIAL AND METHODS}

On 22 March 2020, one specimen of $C$. aydinensis with total length of $435 \mathrm{~mm}$ and $1040 \mathrm{~g}$ weight (Figure 1) was captured by an angler, used fishing pole ( $0.30 \mathrm{~mm}$ PA) on a boat off 40-50 m far from Akçapınar Stream delta, Gökova Bay at a depth of $1.5 \mathrm{~m}$ (Coordinates:3702'00" N - 2819'45", Figure 2). The bait was rock shrimp (Palaemon sp.). The rainy days had passed some days before, and the weather during fishing was sunny. The alive specimen was too strong and was very fluttering (M. Güven, pers. comm.).

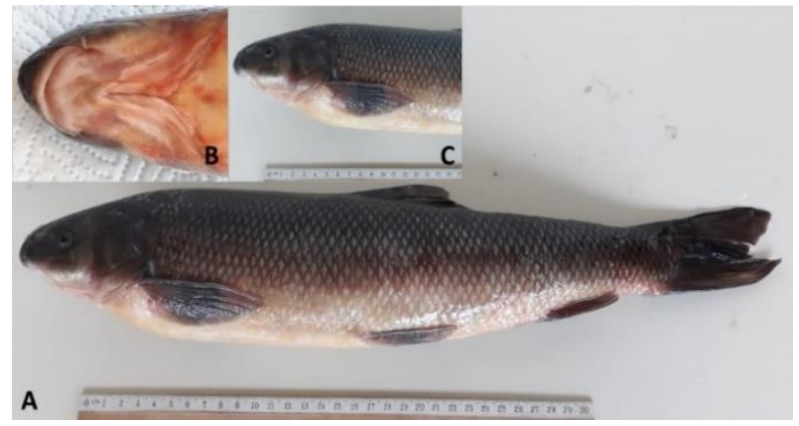

Figure 1. Capoeta aydinensis, captured from Gökova Bay, Aegean Sea (A) whole body, (B) view of the shape of mouth, (C) view of head 


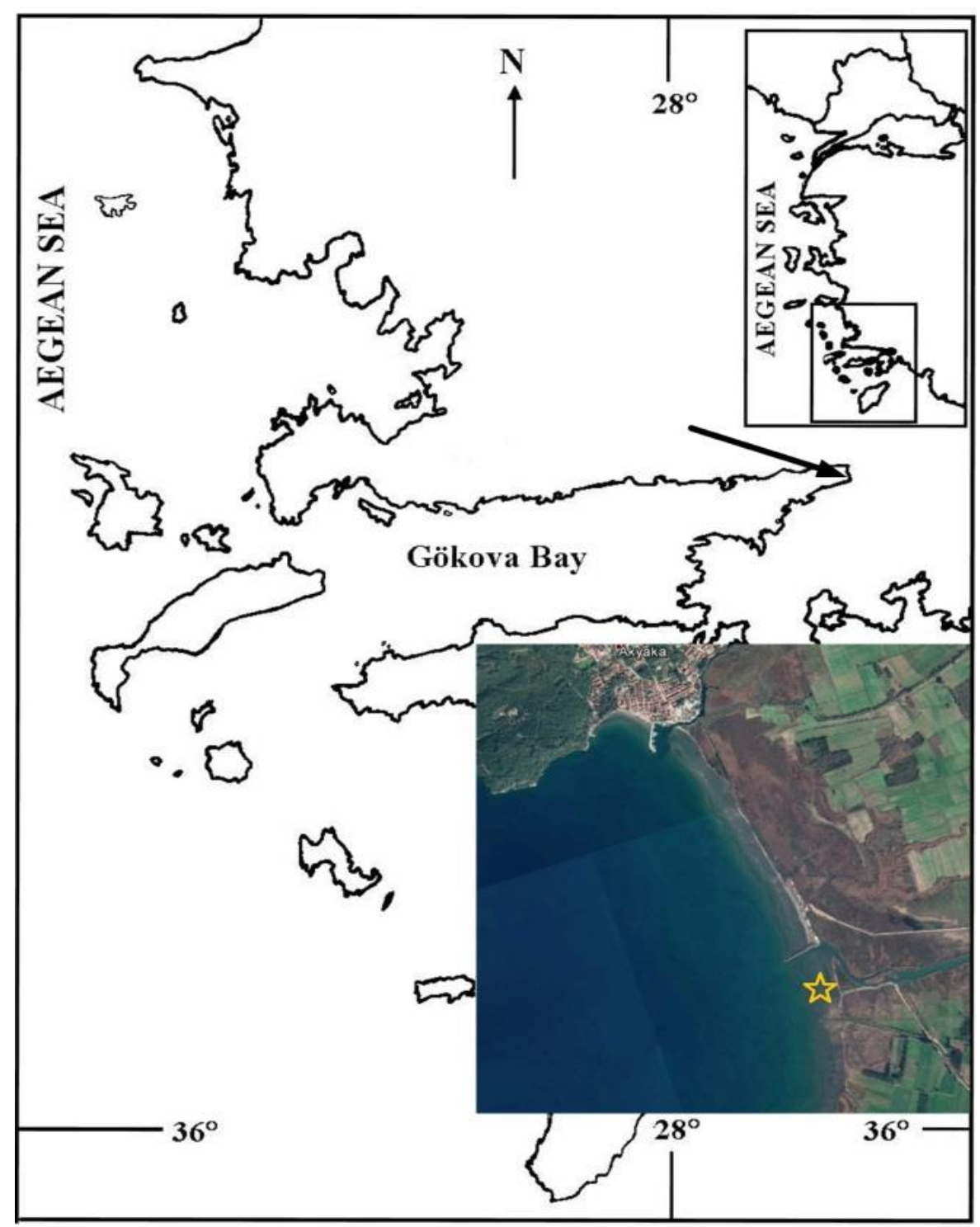

Figure 2. Sampling area (black arrow and yellow star indicate sampling location)

\section{RESULTS AND DISCUSSION}

The specimen was measured to the nearest millimeter (Table 1). All measurements, counts, proportions and color patterns determined are in accordance with the descriptions of Turan et al. (2017) and Froese and Pauly (2019).

In previous studies, Akbaş et al. (2019) reported 364 specimens (TL range: $58-348 \mathrm{~mm}$ ) of $C$. aydinensis from Tersakan Stream (Muğla) during June 2013 - June 2014. Thereafter, 150 specimens (FL range: $130-312 \mathrm{~mm}$ ) of $C$. aydinensis [as $C$. bergamae, it had been name used before new species definition according to Akbaş et al. (2019)] were captured from Topçam Dam Lake in Aydın province (Şaşı, 2009). Turan et al. (2017) also reported 30 specimens (SL range: $117-179 \mathrm{~mm}$ ) in their systematic study. As seen that this paper presents the unique largest size of $C$. aydinensis throughout the Anatolia. However, the occurrence of $C$. aydinensis in a stream delta has not been astonishing since the occurred of $C$. capoeta bergamea in Köyceğiz Lagoon system (Akın et al., 2005). Bohlen (1999) expressed that several freshwater fishes migrates into brackish water for feeding and growth but have to return into waters of lower salinity for spawning. So, this case report presents not only the biggest size but also the unusual habitat of $C$. aydinensis for the Turkish fauna.

\section{ACKNOWLEDGEMENT}

The authors thank angler Mr. Mutlu Güven for bringing the fish to our attention. 
Table 1. Morphometric measurements and its percentages in the standard length and in the head length and meristic counts recorded in Capoeta aydinensis, captured from Gökova Bay, Aegean Sea

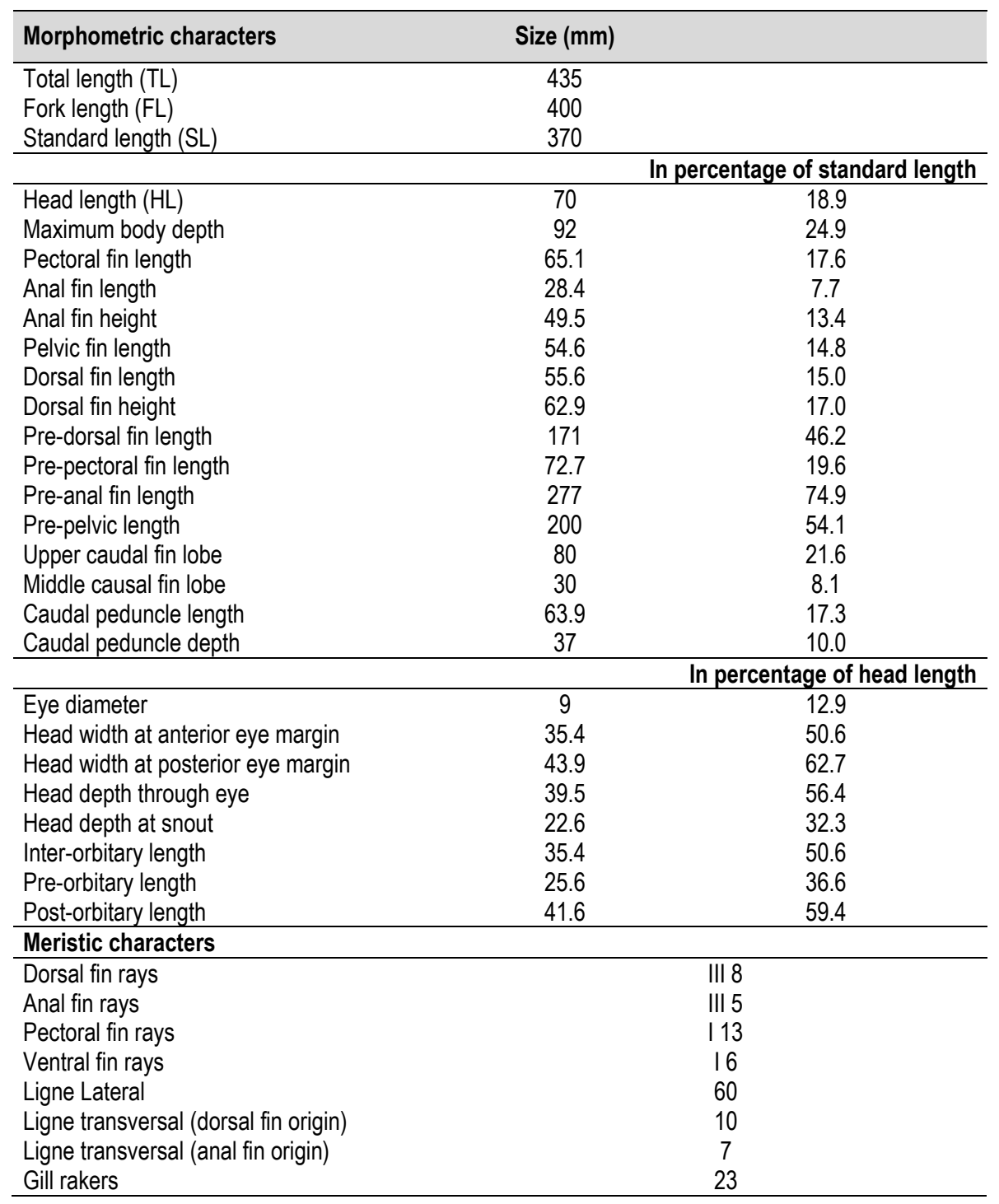

\section{REFERENCES}

Akbaş, F., Tarkan, A.S., Top, N. \& Karakuş, U. (2019). Some biological characteristics, habitat requirements and implications for conservation of endemic freshwater fish Capoeta aydinensis (Turan, Küçük, Kaya, Güçlü \& Bektaş, 2017) in Tersakan Stream (Muğla). Turkish Journal of Bioscience and Collections, 3(2), 4-52. (in Turkish). DOI:10.26650/tjbc.20190009

Akın, S., Buhan, E., Winemiller, K.O. \& Yılmaz, H. (2005). Fish assemblage structure of Köyceğiz Lagoon Estuary, Turkey: Spatial and temporal distribution patterns in relation to environmental variation. Estuarine, Coastal and Shelf Science, 64:671-684.

Bohlen, J. (1999). Influence of salinity on the early development in the spined loach, Cobitis taenia. Journal of Fish Biology, 55: 189-198.
Froese, R. \& Pauly, D. (2019). FishBase. World Wide Web electronic publication. www.fishbase.org, version (12/2019). (Accessed 17 April 2020).

Şaşı, H. (2009). Determination of flesh productivity of Caucasian barb (Capoeta bergamae Karaman, 1969) in living Topçam Dam Lake in the south Aegean Region (Turkey). Ege Journal of Fisheries and Aquatic Science, 26, 35-38.

Turan, D., Küçük, F., Kaya, C., Güçlü, S.S. \& Bektaş, Y. (2017). Capoeta aydinensis, a new species of scraper from southwestern Anatolia, Turkey (Teleostei: Cyprinidae). Turkish Journal of Zoology, 41: 436-442. DOI:10.3906/zoo-1510-43 